\title{
Resistance factor calibration for cold-formed steel compression members
}

\section{Calibração de coeficiente de ponderação da resistência de membros comprimidos de perfis formados a frio}

Marcilio S. R. Freitas

Departamento de Engenharia Civil, Escola de Minas,

Universidade Federal de Ouro Preto. marcilio@em.ufop.br

\section{André L. R. Brandão}

Universidade Federal de Itajubá,

Campus Itabira.

andreriqueira@unifei.edu.br

Arlene M. S. Freitas

Departamento de Engenharia Civil, Escola de Minas,

Universidade Federal de Ouro Preto. arlene@em.ufop.br

\section{Resumo}

O objetivo desse artigo é apresentar uma revisão do procedimento de calibração do coeficiente de ponderação da resistência para um dado índice de confiabilidade alvo. Coeficientes de ponderação da resistência, para colunas de perfis formados a frio, são calculados com um método de confiabilidade de primeira ordem e segundo momento. Foi montado um banco de dados com 323 ensaios de colunas de perfis formados a frio, carregadas, concentricamente, com seções U e U enrijecido, e foram obtidas estatísticas para a relação carga de ensaio versus carga predita para os três métodos disponíveis na Norma Brasileira para perfis formados a frio: o Método da Largura Efetiva (MLE), o Método da Seção Efetiva (MSE) e o Método da Resistência Direta (MRD). Para a combinação de carga normal, relação carga permanente / carga variável de $1 / 3$ e índice de confiabilidade alvo $\beta_{o}=2.5$, os coeficientes de ponderação da resistência calculados para os três métodos são consistentes com o valor especificado pela Norma Brasileira. Para todos os métodos, com o índice de confiabilidade alvo $\beta_{\mathrm{o}}=3.0$, os coeficientes de ponderação da resistência calculados são maiores que os especificados pela Norma Brasileira.

Palavras-chave: Perfis formados a frio, membros comprimidos, calibração, índice de confiabilidade, confiabilidade estrutural.

\begin{abstract}
The objective of this paper is to provide a review of the calibration procedure of the resistance factor for a target reliability index. Resistance factors for cold-formed steel columns are calculated with a first order second moment reliability approach. A test database of 323 cold-formed steel columns concentrically loaded with plain and lipped C-section was assembled, and test-to-predicted statistics were obtained for the three design methods available in Brazilian cold-formed steel code: the Effective Width Method (EWM), the Effective Section Method (ESM) and the Direct Strength Method (DSM). For the normal load combination, dead-to-live load ratio of 1/3, and target reliability index $\beta_{o}=2.5$, the calculated resistance factors, $\gamma$, for the three methods are consistent with current value specified by Brazilian code. For all methods, with target reliability index $\beta_{o}=3.0$, the calculated resistance factors, $\gamma$, are higher than the current value used in Brazilian code.
\end{abstract}

Keywords: Cold-formed steel, compression members, calibration, reliability index, Structural Reliability. 


\section{Introduction}

The fundamental aim of structural reliability analysis is the determination of the reliability of structures under consideration of the uncertainties associated with the resistances and loads. The structural performance is assessed by means of models based on physical understanding and empirical data. Due to idealizations, inherent physical uncertainties and inadequate or insufficient data the models themselves and the parameters entering the models such as material parameters and load characteristics are uncertain. Structural reliability theory takes basis in the probabilistic modeling of these uncertainties and provides methods for the determination of the probability that the structures do not fulfill the performance criteria.

\section{Resistance factor calculation}

Currently the relative reliability of structural design rules including the design equations for CFS members is described in terms of a reliability index, commonly denoted as $\beta$. A higher value of $\beta$ indicates a higher reliability. A widely used method of computing the reliability

where $\mathrm{R}_{\mathrm{m}}$ and $\mathrm{Q}_{\mathrm{m}}$ are the mean nominal resistance and load effect, respectively,

where:

$\mathrm{R}_{\mathrm{n}}=$ nominal resistance

$\mathrm{P}_{\mathrm{m}}=$ mean ratio of experimental to calculated results

$\mathrm{M}_{\mathrm{m}}=$ mean ration of actual yield point to minimum specified value

$\mathrm{F}_{\mathrm{m}}=$ mean ratio of actual to specified column dimensions

$c=$ coefficient

$\mathrm{D}_{\mathrm{m}}=$ mean dead load intensity

$\mathrm{L}_{\mathrm{m}}=$ mean live load intensity

$\mathrm{D}_{\mathrm{n}}=$ nominal dead load intensity
By means of structural reliability methods the code formats of the design codes, i.e., the design equations, characteristic values and resistance factors may be chosen such that the level of reliability of all structures designed according to the design codes is same. This process including the choice of the desired level of reliability or "target reliability" is usually understood as "code calibration". Reliability based code calibration has been formulated by several researchers (Hsiao, 1989; Ravindra and Galambos, 1978).

This work shows a study of the level of reliability of cold-formed steel (CFS) column designed by the Brazilian code. The aim of this study is the assessment of the reliability index $\beta$ for two differents

index $\beta$ is the First Order Second Moment method - FOSM (Cornell, 1969; Ravindra and Galambos, 1978; Ellingwood et al., 1980, Freitas et al., 2007). Using this index, the target value, $\beta$, for cold-formed steel compression members usually are 2.5 for Load and Resistance Factor Design

$$
\beta=\frac{\ln \left(\frac{R_{m}}{Q_{m}}\right)}{\sqrt{V_{R}^{2}+V_{Q}^{2}}}
$$

while $V_{R}$ and $V_{Q}$ are the corresponding coefficients of variations. These terms are

$$
\begin{gathered}
R_{m}=R_{n}\left(P_{m} M_{m} F_{m}\right) \\
Q_{m}=c\left(D_{m}+L_{m}\right) \\
V_{R}=\sqrt{V_{P}^{2}+V_{M}^{2}+V_{F}^{2}} \\
V_{Q}=\frac{\sqrt{\left(D_{m} V_{D}\right)^{2}+\left(L_{m} V_{L}\right)^{2}}}{D_{m}+L_{m}}
\end{gathered}
$$

$\mathrm{L}_{\mathrm{n}}=$ nominal live load intensity

$\mathrm{V}_{\mathrm{P}}^{\mathrm{n}}=$ coefficient of variation of experimental to calculated results

$\mathrm{V}_{\mathrm{M}}=$ coefficient of variation reflecting material properties uncertainties

$\mathrm{V}_{\mathrm{F}}=$ coefficient of variation reflecting geometric uncertainties

$\mathrm{V}_{\mathrm{D}}=$ coefficient of variation of the dead load intensities

$\mathrm{V}_{\mathrm{L}}=$ coefficient of variation of the live load intensities

Load Statistics were analyzed in El- load combinations: (i) $1.2 \mathrm{D}_{\mathrm{n}}+1.6 \mathrm{~L}_{\mathrm{n}}$ and (ii) $1.25 \mathrm{D}_{\mathrm{n}}+1.5 \mathrm{~L}_{\mathrm{n}}$ and two dead-to-live load ratios of $1 / 5$ and $1 / 3$, and the assessment of the resistance factor for a target reliability index. A widely used method of computing the reliability index $\beta$ is the First Order Second Moment method (Hsiao, 1989). The results were compared with the target reliability indexes of 2.5 and 3.0, the same levels used in AISI S100 (2007). The study includes the calibration procedure, i.e., the assessment of the resistance factor $\gamma$ for the load combinations defined. The test-to-predicted strength statistics are employed with the first order second moment method (FOSM).

(AISI-LRFD) and 3.0 for Limit States Design (AISI-LSD). The method assumes a lognormal distribution for the resistance $R$ and the load $Q$, so that the reliability index $\beta$ is computed from:

defined by Eqs. (2) to (5).

lingwood et al. (1980), where it was show that $D_{m}=1.05 D_{n}, V_{D}=0.10, L_{m}=L_{n}$, $V_{L}=0.25$. Resistance factors, $\phi$, are used with the LRFD and LSD design methods in AISI-S100 (2007) to reduce the nominal resistances. They are determined in conformance with load factors to provide a target reliability index, $\beta_{0}$. A satisfactory design can be obtained by equating the factored resistance to the factored loads: 
$\phi R_{n}=c\left(\gamma_{D} D_{n}+\gamma_{L} L_{n}\right)=\left(\gamma_{D} \frac{D_{n}}{L_{n}}+\gamma_{L}\right) c L_{n}$

where $\gamma_{D}$ and $\gamma_{L}$ are the dead and live load factors, respectively, such that the load combinations are $1.2 \mathrm{D}_{\mathrm{n}}+1.6 \mathrm{~L}_{\mathrm{n}}$ for AISI-LRFD and $1.25 \mathrm{D}_{\mathrm{n}}+1.5 \mathrm{~L}_{\mathrm{n}}$ for AISI-

The reliability index can be obtained

If Chapter F of AISI S100 (2007) is

LSD and ABNT NBR 14762 (2010). The dead-to-live load ratios, $\mathrm{D}_{\mathrm{n}} / \mathrm{L}_{\mathrm{n}}$, are $1 / 5$ in AISI-LRFD and $1 / 3$ in AISI-LSD. In the format of the Brazilian code

$$
\gamma=\frac{\left(1,05 \frac{D_{n}}{L_{n}}+1\right)}{\left(\gamma_{D} \frac{D_{n}}{L_{n}}+\gamma_{L}\right)} \frac{e^{\beta_{0} \sqrt{V_{R}^{2}+V_{Q}^{2}}}}{\left(M_{m} F_{m} P_{m}\right)}
$$

as a function of $\gamma$ :

$$
\beta=\frac{\ln \left[\frac{\left(\gamma_{D} \frac{D_{n}}{L_{n}}+\gamma_{L}\right)}{\left(1,05 \frac{D_{n}}{L_{n}}+1\right)}\right] \gamma\left(M_{m} F_{m} P_{m}\right)}{\sqrt{V_{R}^{2}+V_{Q}^{2}}}
$$

is adopted a resistance factor $\gamma=1 / \phi$, therefore, for ABNT NBR 14762 (2010)

$$
\begin{gathered}
\gamma_{F}=\frac{\left(1,05 \frac{D_{n}}{L_{n}}+1\right)}{\left(\gamma_{D} \frac{D_{n}}{L_{n}}+\gamma_{L}\right)} \frac{e^{-\beta_{0} \sqrt{V_{M}^{2}+V_{F}^{2}+C_{P} P_{p}^{2}+V_{Q}^{2}}}}{\left(M_{m} F_{m} P_{m}\right)} \\
\beta_{F}=\frac{\left[n\left[\frac{\left(\gamma_{D} \frac{D_{n}}{L_{n}}+\gamma_{L}\right)}{\left(1,05 \frac{D_{n}}{L_{n}}+1\right)}\right] \gamma\left(M_{m} F_{m} P_{m}\right)\right.}{\sqrt{V_{M}^{2}+V_{F}^{2}+C_{P} V_{P}^{2}+V_{Q}^{2}}}
\end{gathered}
$$

considered, alternative expression for (7)

\section{Statistical data on material and sectional properties and column test database}

Bias and variability in the predicted column capacity are accounted for with a material factor $M$ (related to steel yield stress), a fabrication factor $\mathrm{F}$ (related to column dimensions), and a professional factor P (quantifies the accuracy of capacity predictions relative to tests). The mean values and coefficients of variation

Table 1

Statistical data for the determination of resistance global partial factor.

\section{Strength prediction methods}

Currently, three basic design methods for cold-formed steel members are formally available in Brazilian specification ABNT NBR 14762 (2010): the traditional Effective Width Method (EWM), the Effective Section Method (ESM) and the Direct Strength Method for material properties $\left(\mathrm{M}_{\mathrm{m}}, \mathrm{V}_{\mathrm{M}}\right)$ and fabrication variables $\left(\mathrm{F}_{\mathrm{m}}, \mathrm{V}_{\mathrm{F}}\right)$ adopted in this work were taken from Table 17 in NBR 14762(2010). The relevant portions for Cold-formed steel (CFS) compression members of Table 17 are summarized in Table 1.

The CFS column test database con-

\begin{tabular}{c|c|c|c|c}
\hline Type of Component & $\mathbf{M}_{\mathbf{m}}$ & $\mathbf{V}_{\mathbf{M}}$ & $\mathbf{F}_{\mathbf{m}}$ & $\mathbf{V}_{\mathbf{F}}$ \\
\hline Concentrically Loaded Compression Members & 1.10 & 0.10 & 1.00 & 0.05 \\
\hline
\end{tabular}

(DSM). DSM predicts column strength using the elastic buckling behavior of the whole cross-section. Unlike the EWM, DSM does not quantify the cross-section instabilities "element-byelement" (Shafer, 2002). The strength approach proposed by the ESM is tains a total of 323 columns tests from 13 different experimental programs (see Tab. 2 ). The mean and coefficient of variation, respectively, $\mathrm{P}_{\mathrm{m}}$ and $\mathrm{V}_{\mathrm{p}}$ for the professional factor will be calculated with the column test database and the prediction methods in ABNT NBR 14762 (2010). 


\begin{tabular}{c|c|c}
\hline Reference & Nr. tests(N) & Section type \\
\hline Batista (1989) & 12 & Lipped C \\
\hline Chodraui (2006) & 16 & Plain C, Lipped C \\
\hline Dat (1980) & 43 & Lipped C \\
\hline Desmond et al. (1981) & 7 & Lipped C \\
\hline Loughlan (1979) & 13 & Lipped C \\
\hline Miller and Pekoz (1994) & 44 & Plain C, Lipped C \\
\hline Moldovan (1994) & 64 & Lipped C \\
\hline Mulligan (1983) & 36 & Lipped C \\
\hline Pu et al (1999) & 6 & Lipped C \\
\hline Thomasson (1978) & 14 & Lipped C \\
\hline Young and Hancock (2003) & 42 & Plain C \\
\hline Young and Rasmussen (1998a) & 12 &
\end{tabular}

Table 2

Groups of experimental data and sections type.

\section{Resistance factor results}

Resistance factor obtained for CFS loaded compression members are compared with resistance factor used in Brazilian code ABNT NBR 14762 (2010). The resulting reliability indexes are also compared, for two different load combinations: (i) $1.2 \mathrm{D}_{\mathrm{n}}+1.6 \mathrm{~L}_{\mathrm{n}}$ and (ii) $1.25 \mathrm{D}_{\mathrm{n}}+1.5 \mathrm{~L}_{\mathrm{n}}$ and two dead-to-live load ratios of $1 / 5$ and $1 / 3$, and the assessment of the resistance factor for a target reliability index. The resistance factor, $\gamma$, of 1.2 for concentrically loaded compression members is given by the Brazilian code for cold-formed steel structures. This factor is used in the reliability analysis.

Table 3 presents the results for all the columns in the CFS column test database according to Brazilian Specification, except for ESM method due to columns specimens outside prequalified dimensional limits.

\begin{tabular}{|c|c|c|c|c|c|c|c|}
\hline \multirow{2}{*}{\multicolumn{4}{|c|}{ Strength Predictions Methods }} & \multicolumn{2}{|c|}{$1.2 \mathrm{Dn}+1.6 \mathrm{Ln}$} & \multicolumn{2}{|c|}{$1.25 \mathrm{Dn}+1.5 \mathrm{Ln}$} \\
\hline & & & & \multirow{2}{*}{$\begin{array}{c}\begin{array}{c}\mathrm{Dn} / \mathbf{L n} \\
\mathbf{1} \mathbf{5}\end{array} \\
2.58 \\
\end{array}$} & \multirow{2}{*}{$\begin{array}{c}\mathrm{Dn} / \mathbf{L n} \\
\mathbf{1} \mathbf{3} \\
2.62 \\
\end{array}$} & \multirow{2}{*}{$\begin{array}{c}\text { Dn/Ln } \\
\mathbf{1} / \mathbf{5} \\
2.41 \\
\end{array}$} & \multirow{2}{*}{$\begin{array}{c}\begin{array}{c}\mathrm{Dn} / \mathrm{Ln} \\
\mathbf{1} / \mathbf{3}\end{array} \\
2.47 \\
\end{array}$} \\
\hline \multirow{6}{*}{ EWM } & $\mathrm{N}$ & 323 & $\beta$ & & & & \\
\hline & $\mathrm{P}_{\mathrm{m}}$ & 1.04 & $\gamma_{(2.5)}$ & 1.17 & 1.16 & 1.23 & 1.21 \\
\hline & $\mathrm{V}_{\mathrm{P}}$ & 0.16 & $\gamma_{(3.0)}$ & 1.35 & 1.33 & 1.42 & 1.39 \\
\hline & & & $\beta_{F}$ & 2.58 & 2.62 & 2.41 & 2.46 \\
\hline & & & $\gamma_{F(2.5)}$ & 1.17 & 1.16 & 1.23 & 1.21 \\
\hline & & & $\gamma_{F(3.0)}$ & 1.35 & 1.33 & 1.42 & 1.39 \\
\hline \multirow{6}{*}{ ESM } & $\mathrm{N}$ & 243 & $\beta$ & 2.65 & 2.70 & 2.47 & 2.54 \\
\hline & $\mathrm{P}_{\mathrm{m}}$ & 1.06 & $\gamma_{(2.5)}$ & 1.15 & 1.14 & 1.21 & 1.19 \\
\hline & $\mathrm{V}_{\mathrm{p}}$ & 0.16 & $\gamma_{(3.0)}$ & 1.33 & 1.30 & 1.39 & 1.36 \\
\hline & & & $\beta_{F}$ & 2.64 & 2.69 & 2.47 & 2.53 \\
\hline & & & $\gamma_{F(2.5)}$ & 1.15 & 1.14 & 1.21 & 1.19 \\
\hline & & & $\gamma_{F(3.0)}$ & 1.33 & 1.30 & 1.40 & 1.36 \\
\hline \multirow{6}{*}{ DSM } & $\mathrm{N}$ & 323 & $\beta$ & 2.71 & 2.76 & 2.53 & 2.60 \\
\hline & $P_{m}$ & 1.06 & $\gamma_{(2.5)}$ & 1.13 & 1.12 & 1.19 & 1.17 \\
\hline & $V_{p}$ & 0.15 & $\gamma_{(3.0)}$ & 1.30 & 1.28 & 1.37 & 1.33 \\
\hline & & & $\beta_{F}$ & 2.71 & 2.76 & 2.53 & 2.60 \\
\hline & & & $\gamma_{F(2.5)}$ & 1.13 & 1.12 & 1.19 & 1.17 \\
\hline & & & $\gamma_{E(30)}$ & 1.30 & 1.28 & 1.37 & 1.33 \\
\hline
\end{tabular}

It can be observed from Table 3 that the values of the resistance factor obtained by Eq. (7) are very close to values obtained by Eq. (9), i.e., $\gamma \cong \gamma_{\mathrm{F}}$. For the EWM method, with $\gamma_{D}=1.2, \gamma_{L}=1.6, D_{n} / L_{n}=1 / 5$ and $\beta_{0}=2.5$ (AISI LRFD calibration), the calculated resistance factor, $\gamma$, is 1.17 , or $\phi$ $=0.85$. For the Brazilian code combination $\gamma_{D}=1.25$ and $\gamma_{L}=1.5$, and $\beta_{o}=2.5$, the calculated resistance factor, $\gamma$, with $\mathrm{D}_{\mathrm{n}}$ / $\mathrm{L}_{\mathrm{n}}=1 / 5$ is 1.23 and with $\mathrm{D}_{\mathrm{n}} / \mathrm{L}_{\mathrm{n}}=1 / 3$ is 1.21 which are consistent with $\gamma=1.2$ currently established in ABNT NBR 14672:2010.

For the ESM method, with $\gamma_{\mathrm{D}}=1.2$, $\gamma_{\mathrm{L}}=1.6$ and $\mathrm{D}_{\mathrm{n}} / \mathrm{L}_{\mathrm{n}}=1 / 5$ and $\beta_{\mathrm{o}}=2.5$, the calculated resistance factor, $\gamma$, is 1.15 , or $\phi$ $=0.87$. For the Brazilian code combination $\gamma_{D}=1.25$ and $\gamma_{L}=1.5$, and $\beta_{o}=2.5$, the calculated resistance factor, $\gamma$, with $D_{n} / L_{n}=1 / 5$ is 1.21 and with $D_{n} / L_{n}=1 / 3$ is 1.19 which are consistent with the current value used.

For the DSM method, with $\gamma_{D}=1.2$, $\gamma_{\mathrm{L}}=1.6$ and $\mathrm{D}_{\mathrm{n}} / \mathrm{L}_{\mathrm{n}}=1 / 5$ and $\beta_{\mathrm{o}}=2.5$, the calculated resistance factor, $\gamma$, is 1.13 , or $\phi=0.88$. For the Brazilian code combination $\gamma_{D}=1.25$ and $\gamma_{L}=1.5$, and $\beta_{o}=2.5$, the calculated resistance factor, $\gamma$, with $\mathrm{D}_{\mathrm{r}} /$ $\mathrm{L}_{\mathrm{n}}=1 / 5$ is 1.19 and with $\mathrm{D}_{\mathrm{n}} / \mathrm{L}_{\mathrm{n}}=1 / 3$ is 1.17 which are consistent with $\gamma=1.2$ currently established in ABNT NBR 14672:2010.

For the ESM method, the resistance factor has been computed only for columns specimens whose dimensional properties are within the prescribed limits in Brazilian code. Thus, some test data were excluded from analysis in the ESM formulation.

For all methods, assuming $\gamma_{\mathrm{D}}=1.25$, $\gamma_{\mathrm{L}}=1.5, \mathrm{D}_{\mathrm{n}} / \mathrm{L}_{\mathrm{n}}=1 / 3$ and $\beta_{\mathrm{o}}=3.0$ (AISI LSD calibration), the calculated resistance factors, $\gamma$, are higher than the current value used in Brazilian code.

Table 3

Test-to-predicted statistics, reliability index $\beta$ and resistance factor $\gamma$ (all data). 


\section{Conclusions}

The procedure that has been adopted in the resistance factor calibration like in AISI S100 (2007) was described. So resistance factors for cold-formed steel columns were calculated with a first order second moment reliability approach. A test database of 323 coldformed steel columns was formed, and

\section{Acknowledgements}

The authors are grateful for the sup-

\section{References}

test-to-predicted statistics were obtained for the three design methods formally available in Brazilian code: EWM, ESM and DSM methods.

It could be seen that for load combination $1.25 \mathrm{D}_{\mathrm{n}}+1.5 \mathrm{~L}_{\mathrm{n}}$ and dead-to-live load ratio of $1 / 3$, and target reliability index $\beta_{\mathrm{o}}=2.5$, the calculated resistance factors, $\gamma$, for the three methods are consistent with the current value specified by Brazilian code. For all methods, assuming $\gamma_{D}=1.25, \gamma_{L}=1.5, D_{n} / L_{n}=1 / 3$ and $\beta_{0}=3.0$ (AISI LSD calibration), the calculated resistance factors, $\gamma$, are higher than the current value used in Brazilian code.

port by CAPES, CNPq and FAPEMIG.

AISI-S100 North American Specification for the Design of Cold-formed Steel Structural Members. American Iron and Steel Institute, Washington, D.C., ANSI/ AISI-S100-07, 2007, 183 p.

ASSOCIAÇÃO BRASILEIRA DE NORMAS TÉCNICAS. ABNT NBR 14762:2010 Dimensionamento de estruturas de aço constituídas por perfis formados a frio. Rio de Janeiro, Brasil, 2010.

Batista, E.M Étude de la stabilité des profils parois minces et section ouverte de types $U$ et $C$. Collection des publications de la Faculté des Sciences Appliquées es no. 119, University of Liege, 1989.

BATISTA, E.M. Effective section method: A general direct method for the design of steel cold-formed members under local-global buckling interaction. Thin-Walled Structures; v.48, Issue 4-5, p. 345-356, 2010.

BRANDÃO, A. L. R. Segurança de estruturas em perfis formados a frio. Ouro Preto: Escola de Minas, Universidade Federal de Ouro Preto, 2007. (Dissertação de Mestrado em Engenharia Civil).

CHODRAUI, G. M. B. Análise teórica e experimental de perfis de aço formados a frio submetidos à compressão. São Carlos: Escola de Engenharia de São Carlos, Universidade de São Paulo, 2006. (Tese de doutorado em Engenharia de Estruturas).

CORNELL, A. C. A probability based structural code. ACI Journal, v.66, 12, p.974985, 1969.

DAT, D. T. The strength of cold-formed steel columns. Cornell University, Department of Structural Engineering Report No. 80-4, Ithaca, NY, 1980.

DESMOND, T. P., PEKOZ, T., and WINTER, G. Edge stiffeners for thin-walled members. ASCE Journal of Structural Division, v.107, n.2, p.329-353, 1981.

ELLINGWOOD, B., GALAMBOS, T. V., MACGREGOR, J. G. and CORNELL, C. A. Development of a probability based load criterion for American National Standard A58: Building code requirements for minimum design loads in buildings and other structures. National Bureau of Standards, U.S. Department of Commerce, 1980.

FREITAS, M. S. R., CASTANHEIRA, A. M., and FREITAS, A. M. S. Confiabilidade de vigas metálicas dimensionadas pela norma brasileira NBR 8800. REM-Revista Escola de Minas, Ouro Preto, v.60, n.2, p.261-269, 2007.

HSIAO, L.E. Reliability Based Criteria for Cold-Formed Steel Members. Missouri: University of Missouri-Rolla, Rolla, 1989. (Ph.D. Thesis).

LOUGHLAN, J. Mode interaction in lipped channel columns under concentric or eccentric loading. Glasgow: University of Strathclyde, 1979. (Ph.D. Thesis).

MILLER, T. H., PEKÖZ, T. Unstiffened strip approach for perforated wall studs. ASCE Journal of Structural Engineering, v.120, n.2, p.410-421, 1994.

MOLDOVAN, A. Compression tests on cold-formed steel columns with monosymmetrical section. Thin-Walled Structures, v.20, p.241-252, 1994.

MULLIGAN, G. P. The influence of local buckling on the structural behavior of singly-symmetric cold-formed steel columns. Ithaca, NY: Cornell University, 1983. (Ph.D. Thesis). 
PU, Y., GODLEY, M. H. R., BEALE, R. G., LAU, H. H. Prediction of ultimate capacity of perforated lipped channels. ASCE Journal of Structural Engineering, v.125, n.5, p.510-514, 1999.

RAVINDRA, M. K., GALAMBOS, T. V. Load and resistance factor design for steel. ASCE Journal of the Structural Division, v.104, n.9, p.1337-1353, 1978.

SCHAFER, B. W. Review: the direct strength method of cold-formed steel member design. Journal of Constructional Steel Research; v.4, p.766-778, 2008.

THOMASSON, P. O. Thin-walled C-shaped panels in axial compression. Swedish Council for Building Research. Report: ISSN-91-540-2820-5, 1978.

YOUNG, B., HANCOCK, G. J. Compression tests of channels with inclined simple edge stiffeners. ASCE Journal of Structural Engineering, v.129, n.10, p.1403-1411, 2003.

YOUNG, B., RASMUSSEN, K. J. R. Design of lipped channel columns. ASCE Journal of structural engineering, v.124, n.2, p.140-148, 1998a.

YOUNG, B., RASMUSSEN, K. J. R. Tests of fixed-ended plain channel columns. ASCE Journal of Structural Engineering, v.124, n.2, p.131-139, 1998 b.

Artigo recebido em 12 de julho de 2012. Aprovado em 12 de março de 2013. 